\title{
PURCHASERS' INVOLVEMENT IN SUSTAINABLE DEVELOPMENT: GREAT EXPECTATIONS AND VARIOUS REALITIES
}

\author{
Fabienne FEL \\ ESCP Europe, France
}

\begin{abstract}
The main object of this paper is to determine to what extent Purchasing Departments in French companies do really implement sustainable development policies. In fact, many firms issue communications about their involvement in environmental and social strategies, and it appears that Purchasing Departments should be involved in such policies, because the weight of purchased parts and components is very heavy today. In order to provide a picture of the situation, we conducted a quantitative study among 250 French companies. The first results seemed disappointing, because less than 50\% of the firms had already designed sustainable development purchasing strategies. However, we found a strong link between interest for sustainability and the size of the firms. After these first findings, we narrowed the sample to the 101 companies asserting that their purchasing policy included sustainability concerns. The second results were disappointing too, because most of these firms did not implement any real change in their purchasing policies, and did not even set to purchasers any target related to sustainable development. So, we narrowed once more our sample size to the 43 firms which were really incorporating sustainable development concerns into their policies. We found that these companies were conducting effective changes : they measure the performance of their suppliers more often than the others in our initial sample, they demand more ISO14001 certificates from
\end{abstract}

suppliers based in low cost countries. The necessary changes linked to sustainability induce an increased number of concrete actions (more requests for new service providers, additional 'green' purchases, more frequent change of logistics channels in order to generate less pollution, a greater number of remote suppliers during call for tenders, as well as a greater number of severed contracts with suppliers who do not conform to the firm's sustainability regulations). Similarly, these 43 companies have a more positive outlook on the changes induced by sustainability, judging it to be an apt influence on supplier's offers, generating a partnership spirit and reducing global costs of Purchasing.

So, it appears that there is a wide gap between firms using the concept of "sustainability" as an advertising argument, and firms really implementing changes in order to promote sustainable development among their own departments, and along the supply chain.

Keywords: Sustainable development; purchasing ; change

\section{INTRODUCTION}

The purpose of the present study is to investigate whether sustainable development policies conducted by many companies today are taken into account by Purchasing Departments. According to Preuss (2007), the question of the involvement of purchasers in sustainable development policies is a relatively novel research question. There are lots of communications 
from firms in professional reviews, but little academic research. Moreover, major academic papers dealing with purchasing and sustainability, like those of Preuss, are focused on environmental aspects, and do not deal with the other dimensions of sustainable development, which are social and economical concerns. So, our research question is to determine if purchasers are really involved in sustainable policies, and in this case, if these policies induce real changes in terms of bought products, and in terms of choice of cleaner or more socially responsible suppliers.

This article proceeds in the following way: first, we review the literature about purchasing recent evolutions, and discuss the role that purchasers could play in order both to support the sustainable development policy of their own firm, and to promote sustainability among their suppliers. In a second part, we present our data collection method. Thirdly, we provide the main findings of our research, based on data collected among 250 French companies. As a conclusion, we propose directions for further researches, such as the study of best practices implemented by "citizen firms", or the way they implement them.

\section{LITTERATURE REVIEW}

Sustainable development is defined as development that "meets the need of the present without compromising the ability of future generations to meet their own needs" (Brundtland Commission, 1987). Today, many firms are implementing sustainable development policies, driven by two major forces (Hall and Vredenburg, 2003) : first, there is social and legal pressure to reduce the environmental and social consequences of industrial mass production and consumption. Then, "citizen firms" can aim at increased sales, improved corporate image and enhanced competitiveness (Porter and van der Linde, 1995 ; Pujari and al., 2003).

\section{The Strategic Role of Purchasing}

Nowadays, companies are outsourcing more and more activities, which mean that they are buying an increased share of products and services. As shown by Lysons and Gilingham (2003), the percentage of bought components in the total cost price of Western products has risen from 40 to $65 \%$ (on average) over the last twenty years, because manufacturers are relying more and more on outsourcing, particularly from low cost countries

Therefore, the purchasing function has gained a more strategic position in recent years (Hurkens and Wynstra, 2006). Another explanation for the strategic role of purchasing today is the earlier involvement of suppliers in new product development projects, which aims both to reduce time to market of new products (Fel, 2001), and to expect a growing part of innovation from suppliers (Lamming, 1993). So, purchasers have to widen the scope of their function, by joining earlier on new product development teams, and by setting long term relationships with their main suppliers: many innovations belong to these suppliers, which means that buyers and sellers are linked for long periods of time. As a consequence, one of the main functions of purchasers is to manage these long term relationships.

These evolutions induce the need for real teams of purchasers, able to manage all aspects of the function, from the search for new suppliers to contracts signing and management of the suppliers' performance, in coherence with firm strategy (Trent and Monckza, 2003 ; Loppacher and all, 2006), and the strategic role of purchasing increases when this function is centralized (Johnson and all, 2002).

\section{The Necessary Involvement of Purchasing in Sustainability}

As a consequence of the rising percentage of bought parts and components, the environmental performance of a new product is widely determined by supplier inputs (Preuss, 2005). Regarding sustainability, purchasers face two types of risks:

- Risks related to the product are these of buying components that do not match the environmental criteria defined by the firm in its sustainability strategy. This risk is limited in some sectors by laws about products that can damage public health or environment (European guidelines RoHS or REACH, for instance).

- The "supplier risk" is working with suppliers who use polluting production methods, or fail to respect basic labour rights ; this last risk is greater today as, increasingly, firms are trading with suppliers located in low cost countries, where workers' rights are not always respected. Some well-known problems, like the ones of Nike or Gap, whose Chinese or Indian suppliers made children work, have widely and publicly illustrated this risk.

But regarding sustainability, purchasers face also some opportunities:

- For Preuss (2005), from an ecological point of view, opportunities are purchasing greener parts or components, and then fostering ecological innovation among suppliers.

- The increasing involvement of purchasers in new 
product development teams (Fel, 2001) is also an opportunity for eco-conception : as most firms implement concurrent engineering in order to reduce time to market of new products, Purchasing is involved at an early stage in the design of new products, and can play a role in promoting the design (and not only the purchase) of more ecological parts or components.

- Further more, we can enlarge the idea of Preuss, by taking into account the fact that purchasers are not only responsible for the choice of the product, but also for the choice of the supplier, and for the management of its performance. According with Green and al. (1996), if a firm adopts social standards, the purchasing function can be used to transfer them to suppliers. So, purchasers can induce suppliers in improving their social performance, as well as their environmental performance.

First studies about purchaser's involvement in sustainable development (Bruel and al., 2007) highlight major differences among the organisations surveyed, and show Supplier Performance Management as the main process impacted. For Preuss (2007), purchasers' involvement in ecological innovation could be greater, particularly in SME.

\section{METHODS}

In order to identify the actual practices of Purchasing Departments in terms of sustainability, we directed in 2006 a research project which involved 250 companies. A questionnaire was sent by e-mail to about thousand Purchasing Managers in French companies of all sizes and sectors. We received 261 answers. Some data were missing in some questionnaires, and we at the end obtained 244 usable answers, which means a return rate of near $25 \%$. This rate is very high for this kind of study, and seems indicative of the interest of many companies for this theme.

We collected data about firms, their sustainability policies, and their motivations to implement sustainable development policies; we collected more precise data about real actions implemented by Purchasing Departments, about the existence of progress key indicators, about the management of suppliers performance, and about the outlook of Purchasing managers on sustainable development.

After the initial work of our student (Roiron, 2006), we worked further on the data basis, using SPSS 10.0.

Following our statistical analyzes, we worked successively with three samples: the first sample was comprised of all respondents. In order to understand what firms really do when they assert dealing with sustainable development, we removed from this first group companies which did not implement any sustainability purchasing policy. This second sample was comprised of 101 companies. Then, in order to analyse practices in Purchasing Departments which really follow sustainable objectives, we built a third sample, with only 43 companies, and focused on this last group.

\section{RESULTS AND FINDINGS Definition of the Initial Sample}

The respondents were for the most part Purchasing Managers (52\%) or Purchasers (35\%); The majority came from industrial firms $(75 \%)$, rather than service companies $(25 \%)$.

A first and surprising finding was the overrepresentation of industrial firms in the sample, because there are more service firms than industrial firms in France. But, as industrial firms are more concerned with environmental problems than service companies, and as the most developed pillar of sustainable development is the environmental one, we concluded that, although our sample cannot be considered as statistically representative of French firms, it can be viewed as a representation of firms that tend to really implement sustainability, or that have ideas about this concern.

Therefore, because of the over-representation of industrial firms in the sample, we ran no comparison between industrial sectors, nor between industry and services.

All business sizes were represented, from SMEs (almost $30 \%$ ) to large companies $(37 \%$ of the firms in our sample employ over 5, 000 people), as shown in Figure 1.

\section{Figure 1 : Turn-over of the sample's firms}

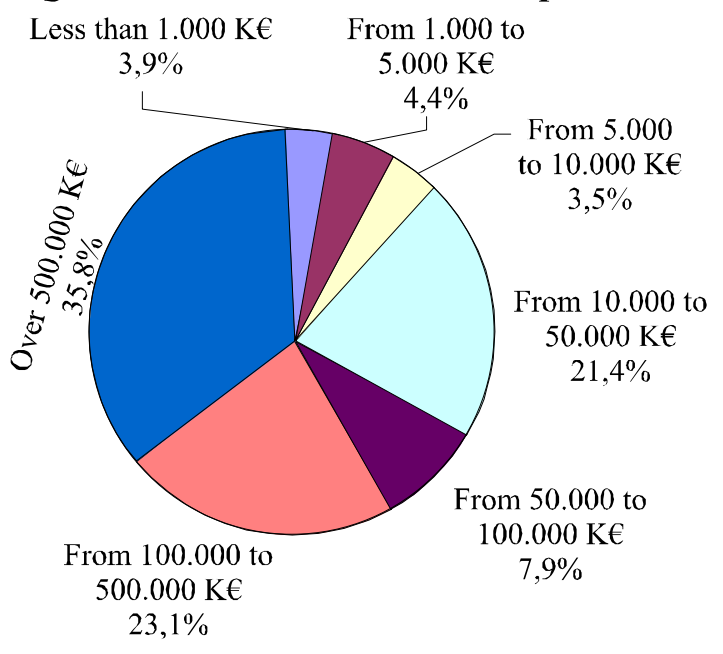




\section{First Results}

$56 \%$ of the firms in our sample asserted that they already integrated sustainability in their purchasing policy $(41 \%)$, or were in the process of doing so $(15 \%)$. Unsurprisingly, it is within the largest companies that this initiative is the most advanced, as almost $80 \%$ of the larger firms replied affirmatively. As shown in figure 2, there is a correlation between company size and the integration of sustainability in purchasing policies, Khi-deux test being significant above $99 \%$.

Figure 2 : Involvement of Purchasing in Sustainability

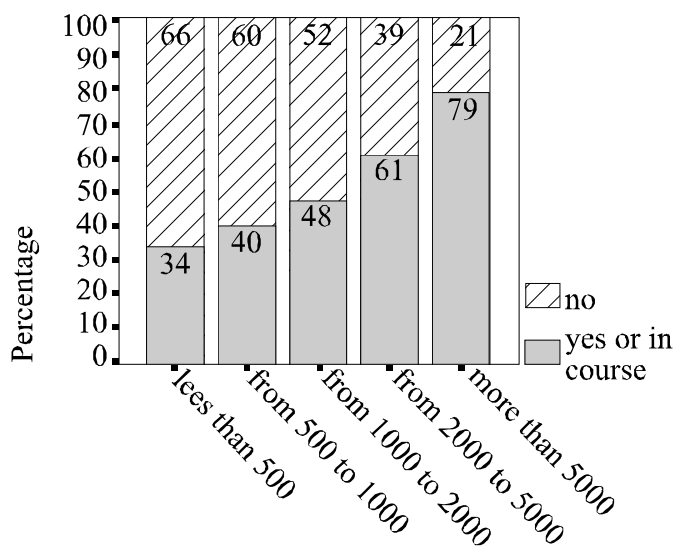

Size of the firm

Quite logically, a correlation also exists between the integration of sustainability in companies purchasing strategies, and their ISO14001 certification, as shown in figure 3 (Khi-deux test is significant above 99\%) : $63 \%$ of certified companies or those currently being certified have integrated sustainability into their purchasing strategy, compared to less than half of those who do not seek certification. However this also signifies that $37 \%$ of ISO 14001 certified companies have not taken into account new demands linked to sustainability in their purchasing strategies, despite the fact that their company is deeply concerned with this issue. It seems then that the changes linked to the implementation of sustainability do not systematically affect the purchasing departments.

Beyond this well-advertised integration of sustainability into purchasing strategies, we sought to gage the extent of the change in the function of Purchase Departments.
Figure 3 : Involvement of Purchasing in Sustainability

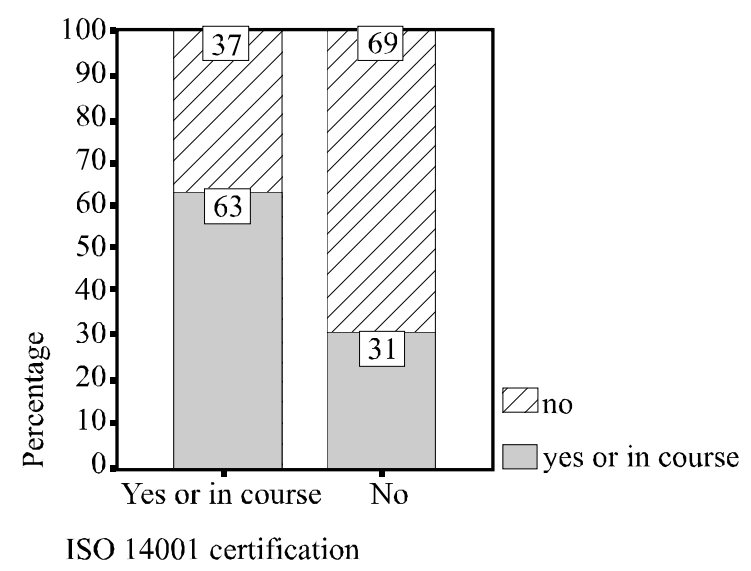

Factors that induce the Change

In order to understand the factors leading to change, we narrowed our initial sample to firms claiming that they have integrated sustainability into their purchasing policies. This second group is comprised of 101 companies

Amongst these companies, it is clear that the change to Purchasing is rather induced than constructed. In $88 \%$ of cases, sustainability had been introduced into purchasing policy following the receipt of a letter from general management, or the release of a purchasing ethics chart, also drawn up at the request from top management. More generally speaking, it is usually under pressure that this policy is adopted by Purchasing Departments: In the first instance, pressure from top management, who defines the company's Sustainability policy ( $48 \%$ of cases), then statutory or legislative pressures $(35 \%)$ and finally customer pressure $(17 \%)$.

Figure 4, which illustrates these figures, could lead us to conclude that in $37 \%$ of cases the Purchasing manager played an important role in the definition of the new strategy, but these figures are put into perspective when we consider that there were several possible answers to the question: thus, out of the 51 companies which indicate their purchasing policy as a cause of change, 29 also include the company's general strategy, and amongst the remainder, 18 state legal pressures or clients demands.

Amongst the 101 companies which claim to have integrated sustainability into their purchasing policies, we tried to identify those which really look for changing this concern into concrete actions. The criteria used to identify these firms was the existence or not of indicators dealing with environmental or social 


\section{Figure 4 : Reasons for Implementing Sustainability Policies in Purchasing}

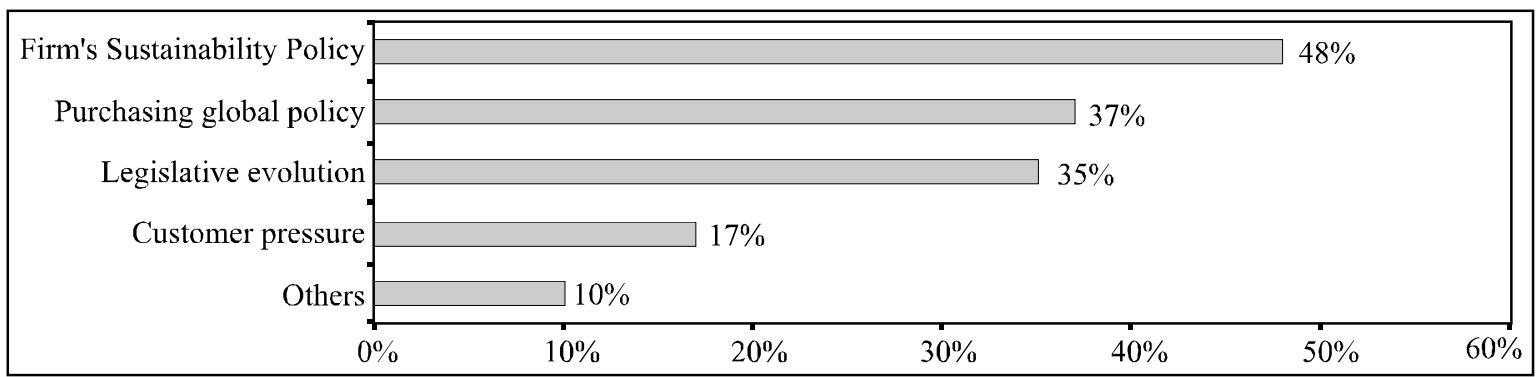

(several answers were possible)

concerns. Once again, the results seemed disappointing: only $48 \%$ of the respondents have to reach objectives dealing with sustainable development, and the definition of such objectives is just a project for 15 $\%$. So, it appears that $36 \%$ of firms that display sustainability purchasing policies do not have any requirement related to this concern, and do not evaluate purchasers using their results in this area.

Literature has shown that all management objectives (in terms of cost reduction, quality improvement, ...) have to be regularly reviewed to be an efficient motivation tool, to allow for progress and to ensure that everyone in the organization makes decisions and follows the lines of action consistent with the firm's strategy.

This is done in only 43 firms in our sample (this means $89 \%$ of the $48 \%$ described above). In these companies, purchasing managers and purchasers have to reach real targets dealing with environmental and/or social concerns, and these targets are regularly reviewed, at least once a year. So, we decided to focus on these 43 companies, which seem to be implementing real sustainability purchasing policies, and to create a third sample with these firms.

\section{Real Changes}

The firms in the third sample have taken real actions in order to implement sustainable development in their purchasing policy, and to promote sustainability among their suppliers. As shown in figure 5, the first action area is to require more environmental and social standards from suppliers based in Low Cost Countries $(84 \%)$, by requiring ISO14001 certifications on the one hand, and respect of social standards on the other hand (these firms require from their suppliers signing international standards, as Global Compact, or signing "home made" supplier charts, which include social standards).

As a consequence, our research shows that the first issue in terms of sustainable purchasing seems to be the management of the suppliers performance in terms of environment and social standards respect.

The second change deals with purchasing "new services", which means training and consulting services in the sustainable development area (81\%). As shown recently by Bruel (2009), purchasers have still difficulties to manage the concept of sustainability, because of their lack of training in this area, and because of the very deep complexity of sustainable development, which includes both environmental and social concepts, with a wide range of different labels and standards (Global Compact, SA 8000 standard, EMAS, ISO 14001 standard...). So, our research shows that firms really involved in sustainable purchasing strategies use training and consulting means to reach their targets.

The third important action implemented by companies of our final sample is to remove, during the call for tenders step, suppliers, which do not respect environmental or social firm's requirements $(71 \%$ of the sample). This finding is close to the first one and coherent with it : quite logically, firms wanting to work with suppliers which respect environmental and social standards do not include "bad" suppliers during call for tender. This seems easier to do than to terminate an existing contract (however, $51 \%$ of the respondents already terminated such a contract for sustainability reasons).

All these findings underline that these 43 firms focus their effort on purchasing process, including the selection of "good" suppliers and the management of their environmental and social performances (which they do with the help of consultants and with purchasers training), rather than on the products themselves : the rate of firms buying "greener products" is lower (57\%) than the previous ones.

Finally, some firms seem to include Purchasing Departments in wider actions, which have an influence on the purchasing policy : $43 \%$ have changed part of their technology for a cleaner one, and $22 \%$ have modified their supply chain, both in order to reduce transportation and pollution, and to buy products made 
by firms located in countries where work laws are always respected.

Figure 5: Real Changes in Final Sample

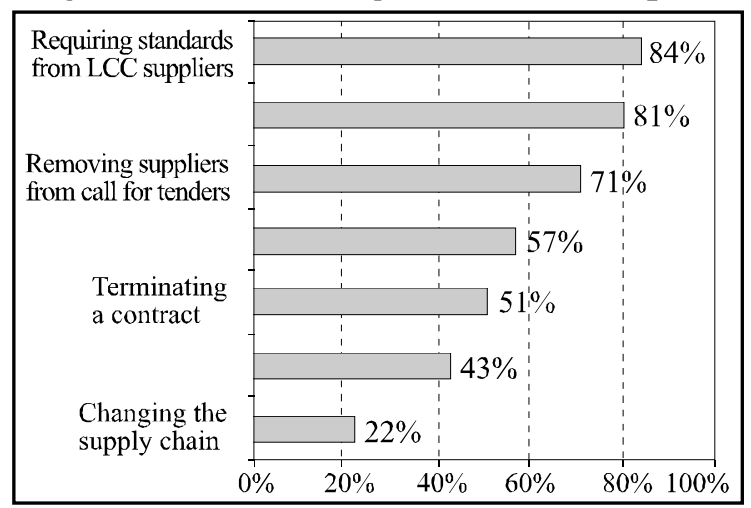

(several answers were possible)

\section{A wide gap between firms}

At the end, we have built three different samples: the first one, with all respondents; the second one, with firms claiming that they are implementing sustainable purchasing policies; the third one, including only firms with real and regularly reviewed sustainable purchasing targets. The comparison between these three samples shows that the more firms are really involved in sustainable purchasing policies, the more they implement real actions, what seems an evident conclusion (Figure 6).

More interestingly, our comparison also evidences that, the more firms are really involved in sustainable purchasing policies, the more they create a positive perception of sustainability, in terms of the need for sustainable development (as an opportunity, and not as a fad), in terms of incentive to green purchasing, of incentive to supplier partnership, and in terms of reduction of the total cost ownership. (Figure 7)

These last findings underline that most respondents have a positive perception of sustainable development. Of particular importance is the last conclusion, which highlights that firms really implementing sustainable development in their purchasing strategies are more convinced than others that sustainability is a good way to reduce Total Cost of Ownership : sustainable development is easier to implement when it can contribute to earn profits, by increasing the turn-over of the firm, or by reducing costs, than when it appears as a source of additional expenses (Reynaud, 2005). So, perception of sustainable development as a cause of costs' reduction by firms really implementing it, allows us to hope that other firms will implement it, -even for financial reasons- and hence contribute to promote environmental and social concerns along the supply chain.

Figure 6: Actions implemented by firms in each sample

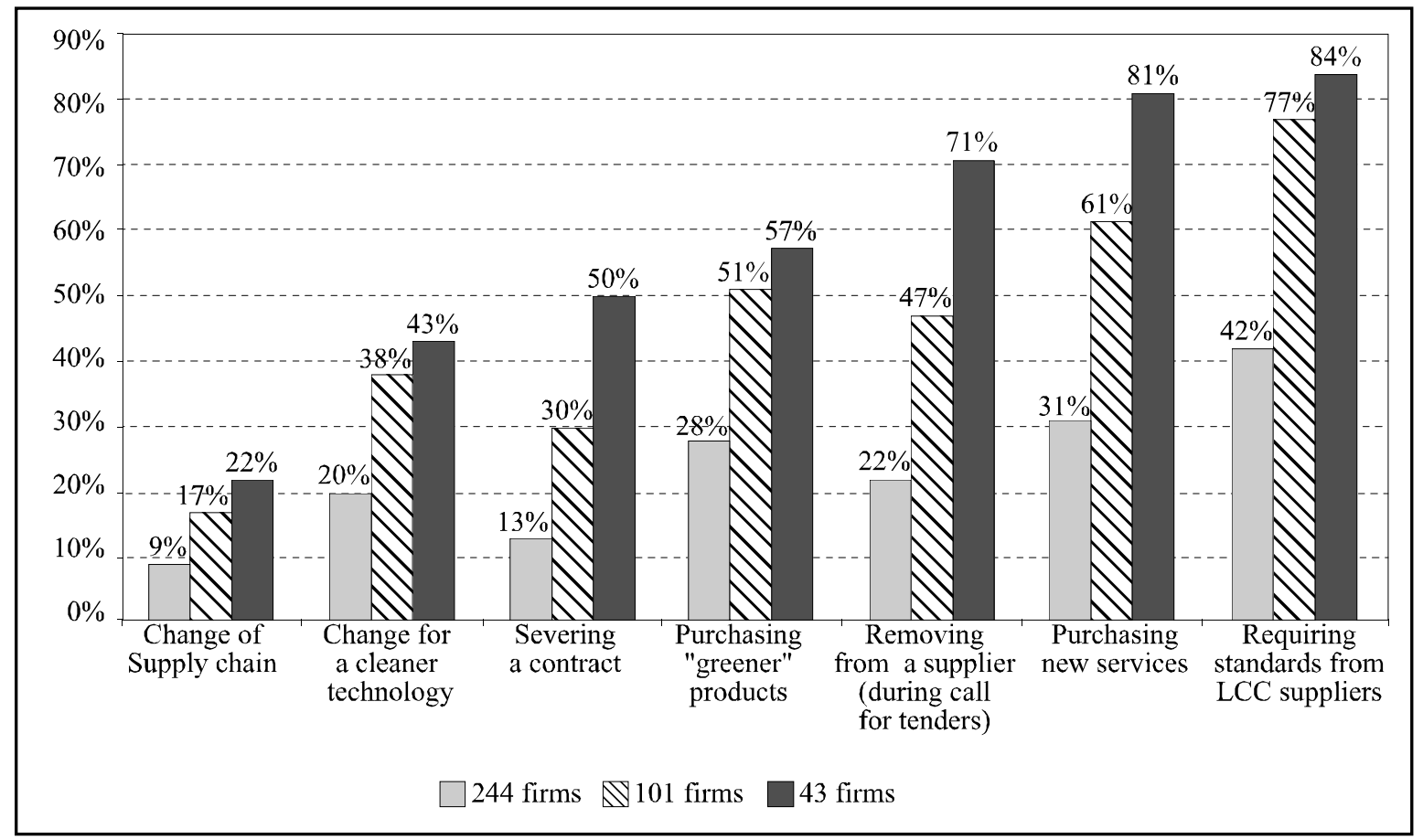


Figure 7 : Perception of Sustainability

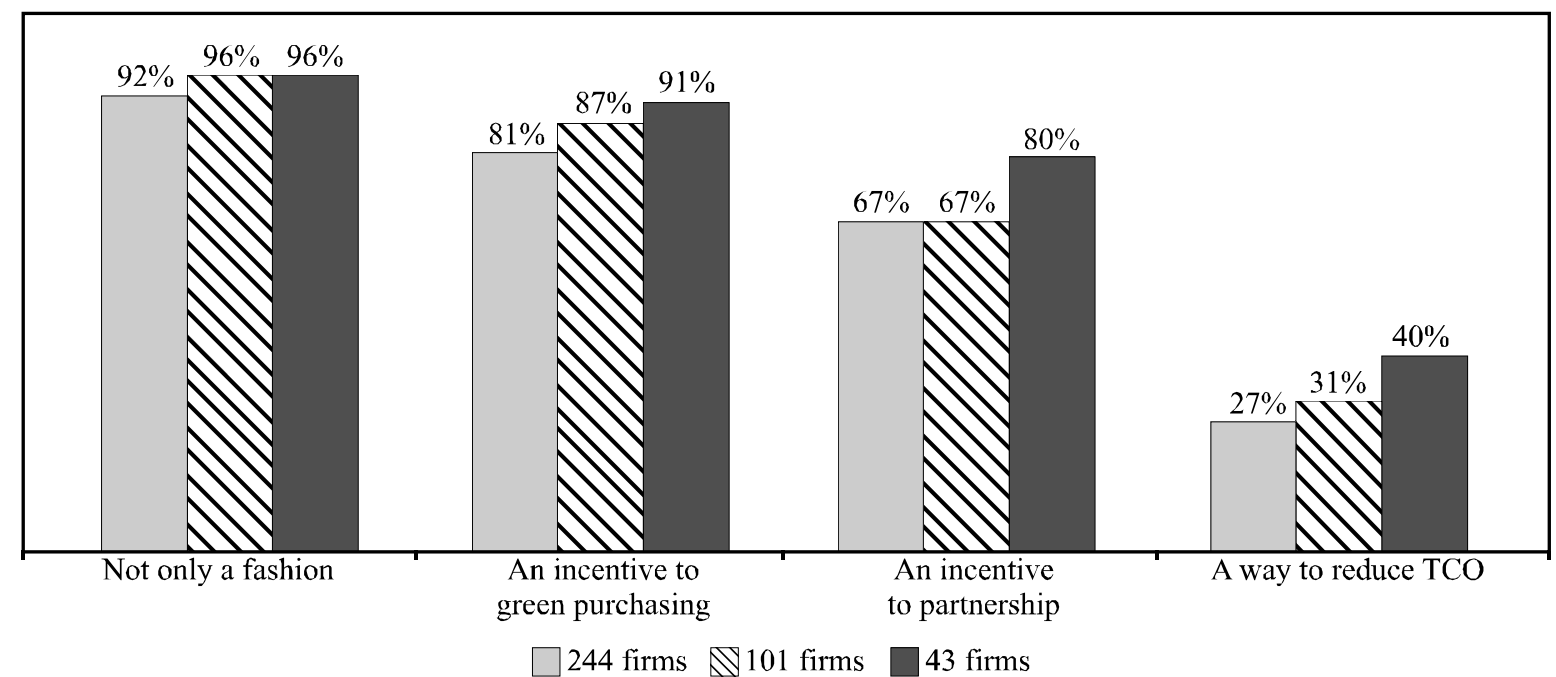

\section{CONCLUSION}

Unsurprisingly, we have shown that there is a strong link between sustainable purchasing policies and the size of companies: as usual, big companies are the first ones making great progress (as with quality improvement in the 80 's, for instance), and smaller companies join later the evolution.

Our study has shown that sustainability's necessity in purchasing policies is still today not widely taken into account: less than half of respondents are implementing sustainable purchasing policies. Amongst those who claim doing it, less than half really measure and review the performance of their Purchasing Department in terms of sustainability. Only 43 companies in our initial sample (less than $18 \%$ ) seem to really implement sustainable purchasing policies.

So, we have defined a typology of companies about involvement of Purchasing Function in sustainable development: companies removed from each successive sample represent three ways of dealing with sustainable development. The first one is ignoring this concern (firms removed from the second sample). The second one is asserting that sustainability is taken into account, but without any requirement from purchasers in this area (firms removed from the third sample). The third one is really involving purchasers in sustainable development, which induce more concrete actions (firms of the third sample).

But the positive perceptions and results of companies of the last sample lead us to think that this attitude can extend to others firms in the future. Firms that really implemented sustainable purchasing policies, with actions devised to avoid working with "uncitizen" suppliers, and to deal with firms following environmental and social issues, have realized concrete actions, and seem satisfied with their results.

It appears that the first step of progress is managing the purchasing process, from the choice of suppliers to the management of suppliers' performance, with the need for purchaser's training and help of consultants. A second level for more mature firms is to integrate the Purchasing function in larger changes, such as changes of technology or modifications of the supply chain, particularly to promote near-sourcing, with lesser transportation needs, less pollution, and the certainty that country's laws comply with basic labour standards.

Our paper presents some limits: first of all, some of the proposed results and findings cannot be generalized (the composition of the initial sample is biased by the over-representation of industrial companies). Another limit is linked to our methodology : by conducting a quantitative survey, we have provided a picture of the situation, but we cannot explain the implementation methods of sustainable purchasing in firms which really try to make progress in this way. The next steps are to list best practices in these firms, and to understand on the one hand, how they are really linked to sustainable development general policy of the firm, and on the other hand, how they can be successfully implemented. These issues will be the subject of our next studies. 


\section{REFERENCES}

Bruel O, Menuet O. and Thaler P., (2007), European Sustainable Procurement Survey, HEC Paris

Bruel (2009), 4th Sustainable Procurement Benchmark Report, HEC PARIS

Brundtland Commission (1987), Our Common Future, Oxford University Press

Fel F., (2001) Les trajectoires de mise en oeuvre des démarches d'ingénierie concourante, Thèse de Doctorat, Paris X Nanterre

Green K., Morton, B. and News, S, (1996), 'Purchasing and Environmental Management : Interaction, policies and opportunities', Business Strategy and the Environment 5 (3), 188-197

Hall K. and Vredenburg H, (2003), 'The challenges of innovating for sustainable development', MIT Sloan Management Review, 45 (1), 61-68

Hurkens K. and Wynstra, J.Y.F. (2006)., 'The concept "Total Value of Ownership" : a case study approach', The Journal of Supply Chain Management, 42(1), 27-37.

Johnson P.F., Klassen R.D, Leenders M.R and Fearon H.E., (2002), 'Determinants of purchasing team usage in the supply chain', Journal of Operations Management, 20(1), p.77-89

Lamming, R,(1993), Beyond Patnership : Strategies for Innovation and Lean Supply, Hemel Hempstead, Prentice Hall

Loppacher J., Luchi R., Cagliano R and Spina G., (2006), 'Global Sourcing and Procurement Strategy : A model of Interrelated Decisions', Supply Chain Forum International Journal, vol7, n ${ }^{\circ}$, p. 34-46

Lysons and Gillingham (2003), Purchasing and Supply Chain Management, 6th edition, Prenctice Hall

Porter M. and van der Linde C., (1995), 'Green and competitive: Ending the stalemate', Harvard Business Review, Sept.-Oct., 120-133

Preuss L., (2005), The Green Multiplier : a Study of Environmental Protection and the Supply Chain, Basingstoke : Palgrave

Preuss, L, (2007), 'Contribution of Purchasing and Supply Management to Ecological Innovation', International Journal of Innovation Management, vol. 11 (4), p. 515-537

Pujari D., Wright G. And Peattie K, (2003), 'Green and competitive : influences on environmental new product development (ENPD) performance', Journal of Business Research, 56(8), 657-671

Reynaud E. (2005), 'Stratégie et Développement durable : à la recherche d'un compromis', Working Paper $n^{\circ} 744$, Université Paul Cézanne, IAE, Aix en Provence

Roiron Lucie, (2006), Les achats et le développement durable dans les entreprises françaises privées, thèse professionnelle de MS, ESCP-EAP, France

Trent R.J. and Monckza R.M. (2003), 'International Purchasing and global sourcing - what are the differences?' Journal of Supply Chain Management, 39 (4), p.26-37

United Nations. (1987). Report of the World Commission on Environment and Development, General Assembly Resolution 42/187 